\title{
Isolation and Characterization of
}

\section{Immunoreactive Somatostatin from}

\author{
Fish Pancreatic Islets
}

\author{
Hideki Oyama, Harry J. Hirsch, Kenneth H. Gabbay, and Alan Permutt, \\ Washington University School of Medicine, Department of Medicine- \\ Metabolism Division, St. Louis, Missouri 63110; Department of Medicine, \\ Children's Hospital Medical Center and Department of Pediatrics, Harvard \\ Medical School, Boston, Massachusetts 02115
}

A B S T R A C T Using a radioimmunoassay with labeled synthetic tetradecapeptide somatostatin, a large amount of immunoreactive somatostatin was found in the principal pancreatic islet of the channel catfish (Ictalurus punctata). The purpose of these experiments was to isolate and characterize the somatostatin-like material. Extracts of islets were chromatographed on a BioGel P-30 column, and over $90 \%$ of the immunoreactive somatostatin migrated with proteins at least twice the size of synthetic tetradecapeptide somatostatin. This fraction was further purified by ion-exchange chromatography on carboxymethyl-cellulose and DEAEcellulose columns. Two peptides were obtained with identical immunoreactivity, which was $\sim 25 \%$ that of the synthetic somatostatin. Each peptide was judged to be $>95 \%$ pure by thin-layer electrophoresis, polyacrylamide gel electrophoresis at $\mathrm{pH} \mathrm{8.9,} \mathrm{and} \mathrm{high-}$ pressure liquid chromatography. Further criteria of purity included amino-terminal analysis of fraction IV yielding only aspartic acid. A total of $1.3 \mathrm{mg}$ of fraction II, and $3.8 \mathrm{mg}$ of fraction IV somatostatin-like peptides were obtained from $10 \mathrm{~g}$ of fresh frozen islets.

Characterization of the two peptides revealed both peptides slightly more acidic than synthetic tetradecapeptide somatostatin. Fraction II had an isoelectric point of 8.0-8.3, and fraction IV 8.3-9.0. Molecular weight estimation by sodium dodecyl sulfate-urea polyacrylamide gel electrophoresis revealed similar mobility of both peptides, between pancreatic polypeptide (mol

Dr. Permutt is the recipient of a U. S. Public Health Service Research and Career Development Award K04-00033. Dr. Gabbay is the recipient of an Established Investigatorship of the American Heart Association. Address reprint requests to Dr. Permutt at Washington University.

Received for publication 27 July 1979 and in revised form 4 January 1980. wt 4,500) and glucagon (mol wt 3,500). The mobility was not altered by reduction, and was approximately twice the size of synthetic tetradecapeptide somatostatin (mol wt 1,800). This confirmed that the peptides were single polypeptide chains and not aggregates, or somatostatin bound to larger proteins. Molecular weight determination by gel filtration chromatography on Bio-Gel P-6 in $8 \mathrm{M}$ urea gave an estimated mol wt of 3,700 . Amino acid analysis of the two immunoreactive somatostatins indicated that they were very similar in composition. Both pancreatic somatostatins $(1 \mu \mathrm{M})$ had full biological activity relative to synthetic somatostatin measured as inhibition of growth hormone release from rat anterior pituitary cells.

\section{INTRODUCTION}

Somatostatin, a tetradecapeptide isolated from ovine hypothalamic extracts, was originally purified because of its ability to inhibit growth hormone secretion from the pituitary (1). After elucidation of its structure, chemical synthesis provided large quantities for further studies. Somatostatin-like immunoreactivity was demonstrated to be widely distributed in the central nervous system, as well as in the gastrointestinal tract (2). In the pancreas, somatostatin-like immunoreactivity was localized to secretion granules within specific islet cells, D cells (3-5). These cells are adjacent to pancreatic islet $\beta$ - and $\alpha$-cells that contain insulin and glucagon, respectively. While pharmacologic studies indicated that synthetic tetradecapeptide (SRIF) ${ }^{1}$ inhibits insulin and glucagon secretion (6), the physiological signifi-

\footnotetext{
${ }^{1}$ Abbreviations used in this paper: CM-cellulose, carboxymethyl cellulose; HPLC, high-pressure liquid chromatography; SDS, sodium dodecyl sulfate; SRIF, synthetic tetradecapeptide somatostatin.
} 
cance of these effects is not known. After ingestion of food, somatostatin from pancreas and gut is released into the blood (7-9). It has been suggested that pancreatic somatostatin biological activity may be mediated through cell-to-cell interactions (paracrine effect) (10), as opposed to a purely endocrine effect.

The chemical nature of pancreatic somatostatin has been studied in a number of species. Rat (11), chicken (12), and pigeon (13) pancreas extracts gave an inhibition curve in a radioimmunoassay which paralleled that of SRIF. The majority of somatostatin-like immunoreactivity from human tumor (14), chicken (12), and pigeon pancreas extracts (13) chromatographed with SRIF by gel filtration, but small amounts of larger forms were also reported. The majority of that extracted from rat pancreas migrated in the void volume of a Sephadex G-25 column (11). Recently, a pancreatic somatostatin was isolated from pigeon pancreas that was identical to tetradecapeptide somatostatin from ovine hypothalamus (13).

To further evaluate the physiological significance of fish pancreatic somatostatin, it is necessary to isolate this peptide in sufficient quantities to characterize it and determine its biological activity. Weir et al. (12) reported high levels of somatostatin in chicken compared to mammalian pancreas $(3.8 \mu \mathrm{g} / \mathrm{g}$ of tissue in the chicken vs. $0.14 \mu \mathrm{g} / \mathrm{g}$ in the rat); channel catfish have been reported to contain even higher levels of pancreatic somatostatin $(5,15,16)$. Using a radioimmunoassay for SRIF, we have detected immunoreactive somatostatin at $100-250 \mu \mathrm{g} / \mathrm{g}$ wet tissue wt in extracts of catfish pancreatic islets. We now report the isolation and partial characterization of two peptides with somatostatin immunologic and biologic activity isolated from catfish pancreatic islets.

\section{METHODS}

Extraction and gel filtration chromatography. Live channel catfish (Ictalurus punctata) were supplied by the Lambrich Bros. Live Fish Co. (Imperial, Mo.). Islets weighing 30-60 mg were removed from live fish $(1-5 \mathrm{lb}$ each) and dropped into liquid nitrogen, and stored at $-70^{\circ}$ until extraction. Frozen tissue $(10 \mathrm{~g})$ was crushed in a tissue pulverizer and extracted in $5 \mathrm{ml}$ of cold tricholoracetic acid (5) with a ground glass homogenizer. Propionic acid $(40 \mathrm{ml})$ was added to this homogenate. (Acid alcohol extracts of islet tissue by the method used for insulin purification [17] yielded $103 \mu \mathrm{g}$ of immunoreactive somatostatin/g tissue compared to $192-237 \mu \mathrm{g} / \mathrm{g}$ tissue with propionic acid.) The homogenate was centrifuged in a refrigerated centrifuge at $4^{\circ} \mathrm{C}, 20,000 \mathrm{~g}$ for $30 \mathrm{~min}$ and the clear supernate removed. The supernate was divided into four equal parts and subjected to gel filtration chromatography on a Bio-Gel P-30 column (100-200 mesh, $4 \times 24 \mathrm{~cm}$; Bio-Rad Laboratories, Richmond, Calif.) equilibrated with 2.5 propionic acid. Fractions of $4.3 \mathrm{ml}$ were collected and the effluent was monitored by an LKB uvicord monitor (LKB Instruments, Inc., Rockville, Md.) at $280 \mathrm{~nm}$. The indicated fractions were pooled, lyophilized, and rechromatographed on the same column. They were then pooled, lyophilized, and further purified by ion-exchange chromatography.

Ion-exchange chromatography. Ion-exchange chromatography was performed similarly to that previously reported (17). A carboxymethyl cellulose $(\mathrm{CM}$-cellulose $)$ column $(10 \times 0.9$ $\mathrm{cm}, \mathrm{CM}-52$ preswollen, microgranular; Whatman Inc., Clifton, N. J.), pre-equilibrated with sodium acetate, $0.024 \mathrm{M}, \mathrm{pH} 4.0$, was used. The sample was applied and the column eluted with at least two column volumes of buffer, until the absorption at $280 \mathrm{~nm}$ returned to base line. This was followed by a continuous sodium chloride gradient elution to a final concentration of $0.35 \mathrm{M}$, at a rate of $20 \mathrm{ml} / \mathrm{h}$. Sample volumes were $2.55 \mathrm{ml}$. A DEAE-cellulose column $(0.9 \times 12 \mathrm{~cm}, \mathrm{DE}-52$ preswollen, microgranular, Whatman Inc.) was equilibrated with $0.01 \mathrm{M}$ Tris-2.5 $\mathrm{M}$ urea buffer, $\mathrm{pH}$ 8.0. Elution with the salt gradient was the same as that for CM-cellulose chromatography, and samples of $1.8 \mathrm{ml}$ were collected. The column eluents were monitored at $280 \mathrm{~nm}$ on an LKB uvicord monitor, and confirmed by measuring their absorbance at $220 \mathrm{~nm}$ with a Gilford spectrophotometer (Gilford Instrument Laboratories Inc., Oberlin, Ohio). All fractions were desalted on a Bio-Gel P-2 column equilibrated with $1 \mathrm{M}$ acetic acid.

Molecular weight determinations. Molecular weight of the purified peptides was estimated by gel filtration in urea and by sodium dodecyl sulfate (SDS)-urea polyacrylamide slab gel electrophoresis. Synthetic somatostatin (Ayerst Laboratories, N. Y.) was reduced and carboxymethylated (CM-SRIF) as described (18), and then applied to a Bio-Gel P-6 column $(0.9 \times 29 \mathrm{~cm}, 0.01 \mathrm{M}$ Tris- $8 \mathrm{M}$ urea, $\mathrm{pH} 8.0)$. The sample volume was $300 \mu$ l. This column was also calibrated with aminoethylated bovine insulin $\alpha$ - and $\beta$-chains. Aminoethylation of bovine insulin (Sigma Chemical Co., St. Louis, Mo.) was performed by the method of Raftery and Cole (19).

SDS-urea polyacrylamide gel electrophoresis was performed by a modification of the method of Swank and Munkres (20), using the discontinuous buffer system of Laemmli $(21)$ in $17.5 \%$ acrylamide (Bio-Rad Laboratories) slab gels with $8 \mathrm{M}$ urea as previously described (17). The protein standards (ovalbumin, mol wt 43,000; chymotrypsinogen, mol wt 23,200; myoglobin, mol wt 17,200; cytochrome C, mol wt 12,000; and bovine insulin, mol wt 5,700 ) were supplied by Sigma Chemical Co. Porcine proinsulin, mol wt 9,000 bovine pancreatic polypeptide, mol wt 4,500 , and porcine glucagon, mol wt 3,500 were supplied by Dr. Ronald Chance, Eli Lilly \& Co., Indianapolis, Ind.

Determination of immunoreactive somatostatin and protein content. Somatostatin immunoreactivity was measured by a previously described radioimmunoassay $(22)$ which utilizes antiserum $\mathrm{H} 30-20$ produced in rabbits immunized with a somatostatin-thyroglobulin conjugate, [ $\left.{ }^{125} I\right]$ tyrosine-11-somatostatin label, and synthetic cyclic somatostatin standards. The antiserum is specific for the central, hydrophobic region of the tetradecapeptide and is most sensitive to alterations in amino acid residues seven and eight. No cross-reactivity was observed for a variety of gastrointestinal peptides including insulin, glucagon, secretin, cholecystokinin-pancreozymin, gastrin, and pancreatic polypeptide. This assay detects as little as $5 \mathrm{pg}$ of somatostatin. Intra-assay variation is $8.5 \%$ and interassay variation is $9.7 \%$. Aliquots of extracts and column fractions were diluted in $0.05 \mathrm{M}$ sodium phosphate buffer, $\mathrm{pH} 7.5$ before assay. Protein determinations were performed by the method of Lowry (23) with bovine insulin as a standard.

Electrophoresis. Thin-layer electrophoresis was performed on cellulose acetate plates $(20 \times 20 \mathrm{~cm}$, Uniplate, Avicel microgranular cellulose, Analtech, Inc., Newark, Del.; Avicel, FMC Corp., Philadelphia, Pa.). The samples (10-20 $\mu \mathrm{g})$ were applied to the plates in 5-19 $\mu$ l of pyridine acetate, $\mathrm{pH} 6.5$, 
and electrophoresed in pyridine acetate at $400 / \mathrm{V}$ for $4 \mathrm{~h}$ at $4^{\circ} \mathrm{C}$. The plates were dried and visualized with fluorescamine (Roche Diagnostics Div., Hoffman-LaRoche Inc., Nutley, N. J.), as previously described (17). 2,4-dinitrophenol-lysine (Sigma Chemical Co.) was used as a standard. Electrophoresis in polyacrylamide slab gels at $\mathrm{pH} 8.9$ was done by the method of Davis (24). The proteins were stained with Coomassie Blue and densitometric scans on a Gilford $2400 \mathrm{~S}$ gel scanner (Gilford Instrument Laboratories, Inc.) at $550 \mathrm{~nm}$ performed (17).

High-pressure liquid chromatography. The apparatus used for high-pressure liquid chromatography (HPLC) consisted of a Varian 8500 model liquid chromatograph, model 8050 autosampler injector (Varian Associates, Inc., Palo Alto, Calif.), and a Vari-Chrom variable wavelength detector, and model 9176 recorder.

HPLC was performed as reverse-phase chromatography on a MCH10 Micropack column $(0.4 \times 30$; Varian Associates, Inc.) containing octadecylsilanyl groups covalently coupled to silica particles. The column was eluted by a linear gradient of $90 \% \mathrm{~A}$ ( $10 \%$ acetonitrile), $10 \% \mathrm{~B}(90 \%$ acetonitrile) to $100 \%$ $\mathrm{B}, \mathrm{pH}$ 4.1. Under these conditions, fish pancreatic somatostatin was clearly separated from SRIF.

Amino acid and end-group analysis. Amino acid composition was determined by the Protein Chemistry Facility at Washington University School of Medicine. Protein was hydrolysed in $6 \mathrm{~N} \mathrm{HCl}$ for 24 and $72 \mathrm{~h}$ and the hydrolysate applied to a Durrum D-500 amino acid analyzer (Durrum Instrument Corp., Sunnyvale, Calif.) to determine the quantity of each of the protein amino acids. End-group analysis was performed by Edman degradation of reduced and carboxymethylated pancreatic somatostatin followed by thin-layer chromatography as described (25).

Bioassay. The biologic activity of purified pancreatic somatostatin was tested by the ability to inhibit growth hormone secretion by primary rat anterior pituitary cell cultures as previously described (26). Each sample was assayed in triplicate.

\section{RESULTS}

\section{Isolation of immunoreactive pancreatic somatostatin}

Isolation of pancreatic somatostatin was achieved by sequential chromatography of islet extracts followed by an assay of each subsequent fraction for immunoreactive somatostatin. A flow diagram of the overall purification scheme is presented in Fig. 1. Gel filtration chromatography on Bio-Gel P-30 yielded four major fractions as indicated in Fig. 2. Greater than $90 \%$ of the immunoreactive somatostatin was found in fraction $C D$. The estimated molecular weight of this fraction was 3,0006,000 as determined by calibration with standard proteins. SRIF chromatographed in fraction E. Since most of the immunoreactive pancreatic somatostatin was in Bio-Gel fraction CD, this fraction was pooled, lyophilized, and rechromatographed on Bio-Gel P-30. The mobility of the immunoreactive somatostatin did not change. This fraction was subjected to chromatography on CM-cellulose at pH 4.0 (Fig. 3). Two major peaks of protein eluted from the column before a salt gradient was applied. After elution with sodium chloride, each fraction indicated was pooled and assayed for immunoreactive somatostatin. Fractions II and IV together

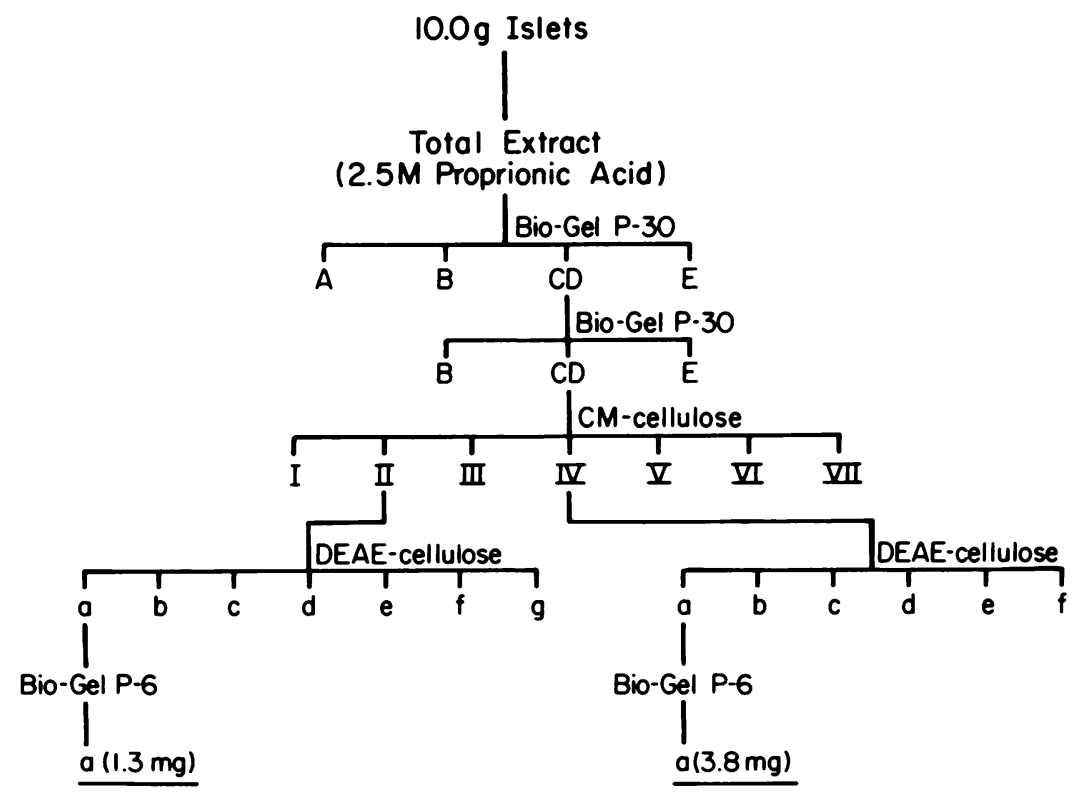

FIGURE 1 Summary of the purification of immunoreactive pancreatic somatostatin from catfish islets. The isolation of pancreatic somatostatin was monitored by a somatostatin radioimmunoassay as described in the Methods. The final yield of pancreatic somatostatin for the two fractions indicated was 1.3 and $3.8 \mathrm{mg}$. 


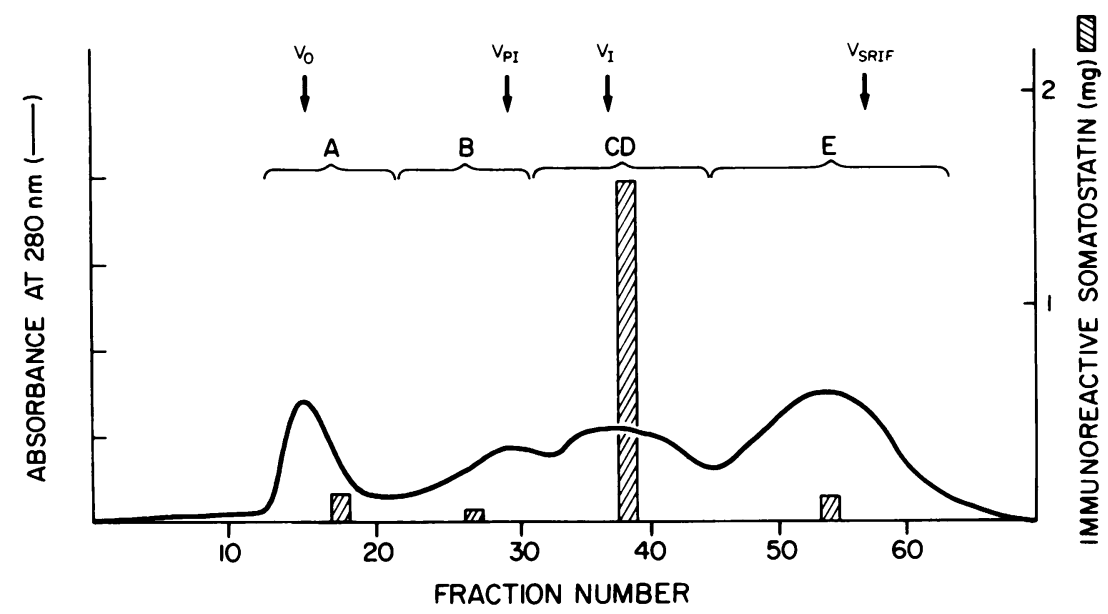

FIGURE 2 Gel filtration chromatography of the acid extract of pancreatic islets. One-fourth of the total extract $(10 \mathrm{ml}$ ) was chromatographed on a Bio-Gel P-30 column as described in the Methods. The indicated fractions (A-E) were pooled. Shaded bars within each fraction represent total immunoreactive somatostatin content from $10 \mathrm{~g}$ islet extract. $V_{0}$, void volume; $V_{\mathrm{Pl}}$, migration of porcine proinsulin; $\mathrm{V}_{\mathrm{I}}$, insulin; $\mathrm{V}_{\mathrm{SRIF}}$, synthetic tetradecapeptide somatostatin.

comprised $85-90 \%$ of the immunoreactive somatostatin applied to the column and these fractions were therefore subjected to further analysis. CM-cellulose fractions II and IV were individually chromatographed on DEAE-cellulose. The results of chromatography on CM-cellulose fraction II on DEAE-cellulose is seen in Fig. 4. One major peak of protein was eluted from the column followed by three protein peaks eluted with the salt gradient. Most of the immunoreactive somatostatin was found in fraction a. DEAE-cellulose chromatography of CM-cellulose fraction IV gave an almost identical pattern of protein and immunoreactive somatostatin (data not shown). The monitoring of purification of immunoreactive pancreatic somatostatin is indicated in Table I.

\section{Characterization of pancreatic immunoreactive somatostatin}

Electrophoresis. Thin-layer electrophoresis of SRIF and CM-cellulose fractions II and IV are seen in Figs. 5 and 6 . Under the conditions of electrophoresis $(\mathrm{pH}$ 6.5) synthetic somatostatin, a basic protein, migrates toward the cathode (Fig. 5, lane 1). CM-cellulose fraction II was seen to be composed of one major and two to three minor peptides, all less basic than synthetic somatostatin. CM-cellulose fraction II was further chromatographed on DEAE-cellulose and separated into fractions IIa-f. Fraction IIa, which accounted for the majority of immunoreactive somatostatin, contained the major peptide with some minor contaminants.

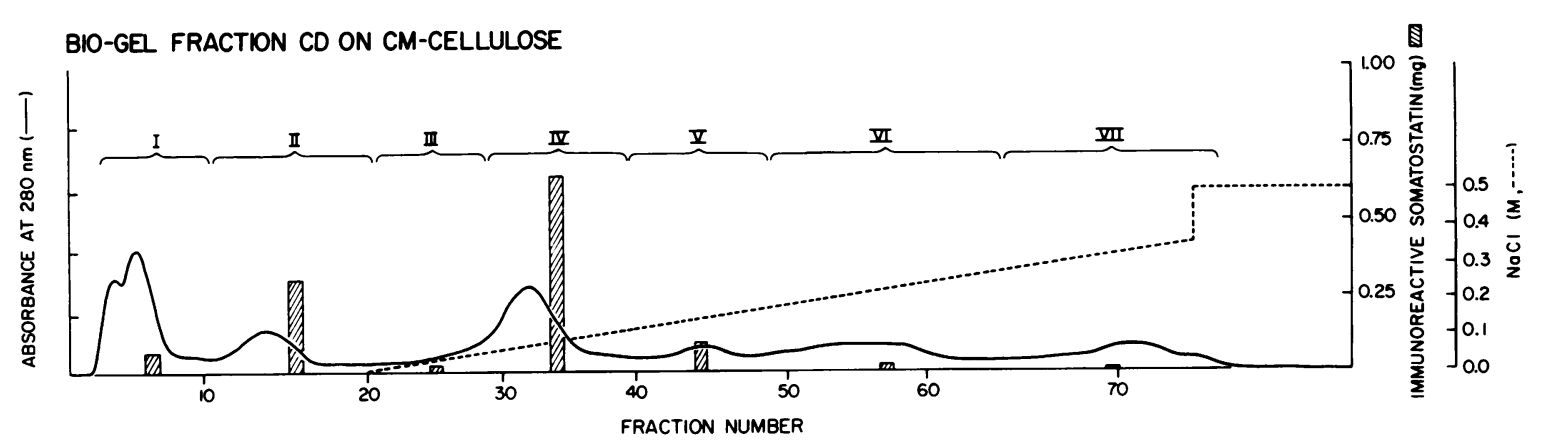

Figure 3 Chromatography of Bio-Gel fraction CD on CM-cellulose. Bio-Gel fraction CD (31.3 $\mathrm{mg}$ ) was dissolved in starting buffer $(0.024 \mathrm{M}$ sodium acetate, $\mathrm{pH} 4.0$ ), applied to a CM-cellulose column, and eluted with a $\mathrm{NaCl}$ gradient (---) as indicated in the Methods. The indicated fractions were pooled, and their content of immunoreactive somatostatin shown by the shaded bars. 
CM-CELLULOSE FXII ON DEAE-CELLULOSE

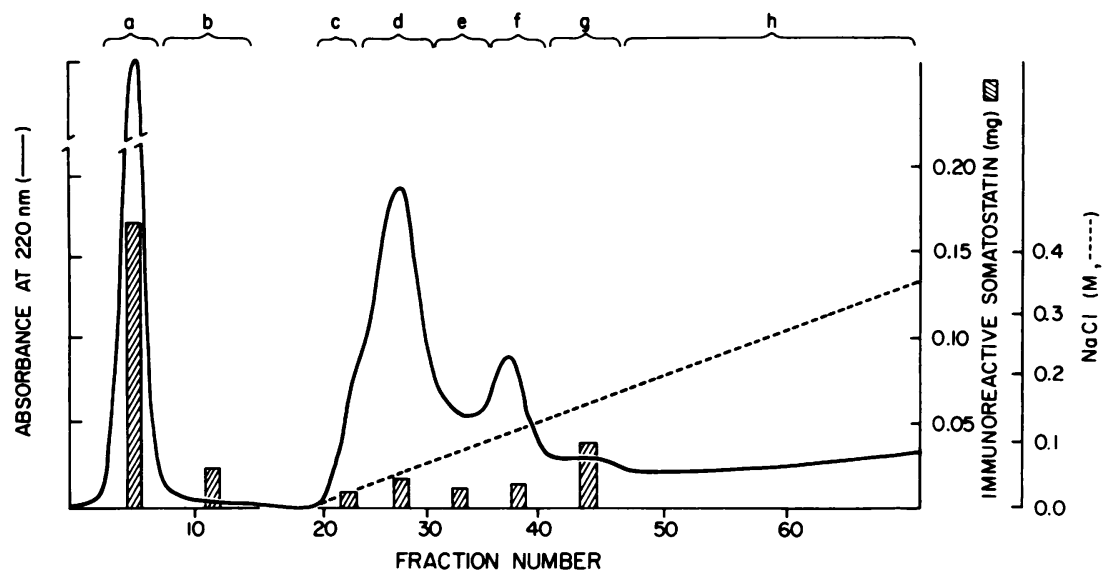

FIgure 4 Chromatography of CM-cellulose fraction II on DEAE-cellulose. C.M-cellulose fraction II $(2.71 \mathrm{mg})$ was dissolved in starting buffer $(0.01 \mathrm{M}$ Tris-2.5 $\mathrm{M}$ urea, $\mathrm{pH} 8.0)$ and applied to a DEAE-cellulose column (DE-52, $0.9 \times 12 \mathrm{~cm}$ ). From fraction 19 the column was eluted by a linear $\mathrm{NaCl}$ gradient (---) to $0.35 \mathrm{M}$ as described in the Methods. The indicated fractions were pooled and the contents of immunoreactive somatostatin shown with shaded bars.

Electrophoresis of CM-cellulose fraction IV was compared to synthetic somatostatin in Fig. 6. Fraction IV contained two major and two minor peptides, again all more acidic than synthetic somatostatin. When CM-cellulose IV was chromatographed on DEAE-cellulose, the highest immunoreactive somatostatin fraction was fraction IVa, which contained one major peptide, also more acidic than synthetic somatostatin. This peptide was slightly more basic than the purified CM-cellulose fraction IIa seen in the last lane of Fig. 6.

The purified pancreatic immunoreactive somatostatins CM-cellulose II DEAE a (IIa), and CM-cellulose IV DEAE a (IVa) were electrophoresed on polyacrylamide

TABLE 1

Purification of Immunoreactive Pancreatic Somatostatin

\begin{tabular}{lccc}
\hline \multicolumn{1}{c}{ Fraction } & $\begin{array}{c}\text { Immunoreactive } \\
\text { somatostatin }\end{array}$ & Protein & $\begin{array}{r}\text { Specific } \\
\text { activity }\end{array}$ \\
& $\mu g$ & $m g$ & $\mu g / m g$ \\
Total* $^{*}$ & 473 & 59 & 8 \\
Bio-Gel CD & 316 & 14.7 & 22 \\
CM II & 70 & 0.56 & 125 \\
CM IV & 127 & 1.19 & 107 \\
CM II DEAE a & 63.7 & 0.26 & 245 \\
CM IV DEAE a & 185 & 0.76 & 245 \\
\hline
\end{tabular}

The immunoreactive somatostatin was monitored by radioimmunoassay and protein by the Lowry procedure, on the extract from $2 \mathrm{~g}$ of fish islets as described in the Methods. Specific activity is defined as the immunoreactive somatostatin $(\mu \mathrm{g})$ divided by the protein $(\mathrm{mg})$ in each fraction.

* Total refers to that found in a propionic acid extract of tissue insoluble in TCA as described in the Methods. gels at $\mathrm{pH}$ 8.9. SRIF and fraction IVa are very basic and did not migrate into the gel at this $\mathrm{pH}$. Fraction IIa, more acidic than fraction IVa, barely entered the gel but migrated as a single band (not shown). Isoelectric focusing was unsuccessful as gradients of $\mathrm{pH}$ above 9 were not satisfactorily obtained. From the mobility of the peptides by thin-layer electrophoresis (pH 6.5 and 8.5) as well as polyacrylamide gel electrophoresis at $\mathrm{pH} 8.9$, a rough estimate of the isoelectric point of fraction IIa was 8.0-9.3, and fraction IVa, 8.3-9.0.

HPLC. Partially purified pancreatic somatostatin (CM-cellulose II) was subjected to reverse-phase HPLC (Fig. 7). After an injection artifact, three peaks were observed. Peak 1 comprised 22 of the $27 \mu \mathrm{g}$ of protein applied, and all of the immunoreactive somatostatin. Peak 1 was subjected to thin-layer electrophoresis and one peptide was observed with mobility identical to the major peptide in fraction IIa.

Molecular weight estimation. To determine whether the purified pancreatic somatostatins were aggregates of tetradecapeptide somatostatin, or somatostatin bound to larger proteins, the proteins were boiled in SDS and electrophoresed on SDS-urea polyacrylamide gels (Fig. 8). The mobility of the immunoreactive somatostatins from fractions IIa (Fig. 8, lane 2) and IVa (Fig. 8 , lane 4) were identical to each other, and were unchanged by the addition of mercaptoethanol (Fig. 8, lanes 3 and 5). While it is difficult to estimate the exact molecular weight of small peptides on SDS-polyacrylamide gels (20), these immunoreactive pancreatic somatostatins are larger than synthetic somatostatin (Fig. 8, lane 6), and have intermediate mobility between 


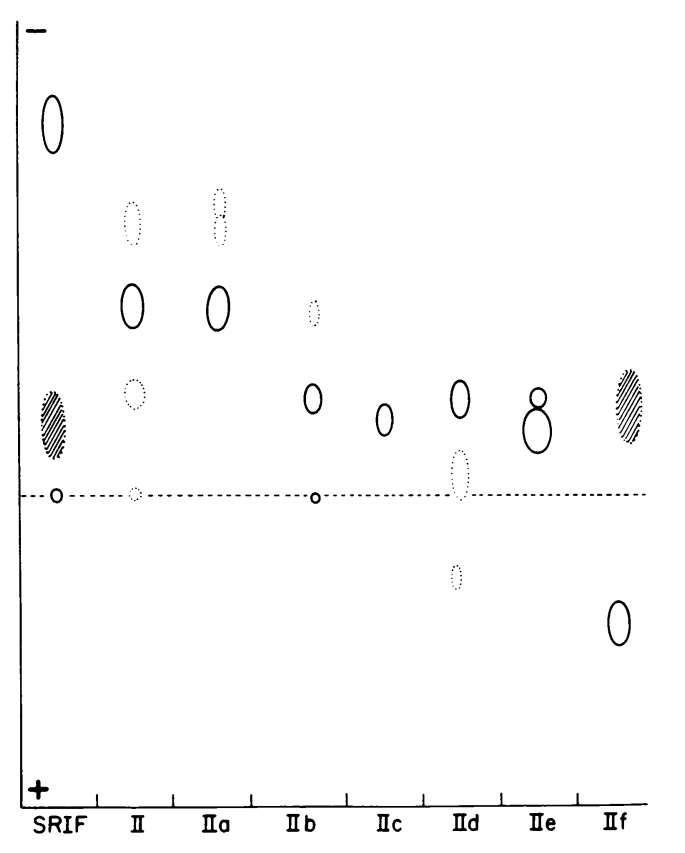

FIGURE 5 Thin-layer electrophoresis of SRIF and pancreatic somatostatin (CM-cellulose II), and the subsequent DEAE fractions a-f. $10-15 \mu \mathrm{g}$ of each peptide fraction was spotted on cellulose acetate thin-layer plates $(20 \times 20 \mathrm{~cm})$ and electrophoresed for $4 \mathrm{~h}$ at $400 \mathrm{~V}, 4^{\circ} \mathrm{C}$ using pyridine acetate buffer, $\mathrm{pH}$ 6.5. The plate was visualized with fluorescamine. The shaded spots in the first and last lanes refer to the mobility of 2,4-dinitrophenol-lysine. The dotted circles refer to poorly visible spots. The dashed line refers to the origin.

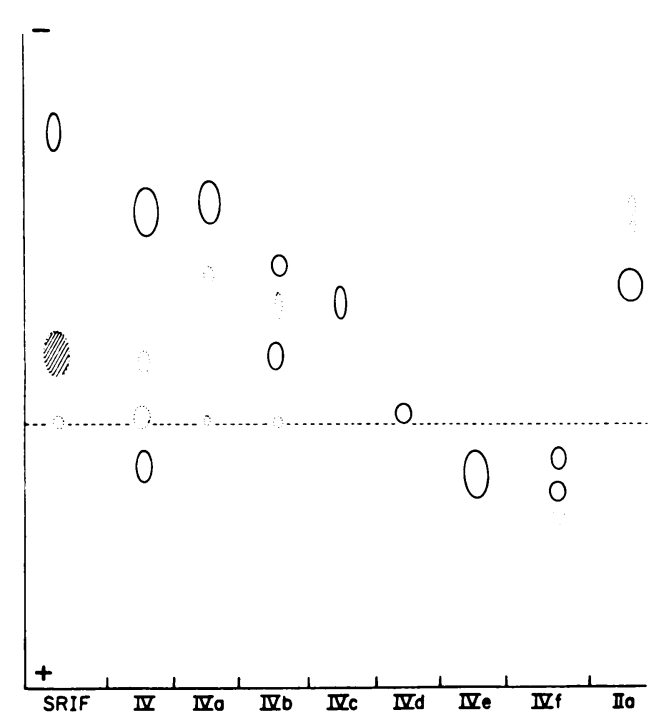

FIGURE 6 Thin-layer electrophoresis of DEAE fractions from CM-cellulose fraction IV compared to SRIF ad purified CM-cellulose IIa. The methods were as described in the legend of Fig. 5. IV: CM-cellulose fraction IV; IVa-IVf: DEAE-cellulose fractions a-f from CM-cellulose fraction IV (shown in Fig. 3); IIa: DEAE-cellulose fraction a from CMcellulose fraction II. Shaded spot represents the migration of 2,4-dinitrophenol-lysine as a standard.

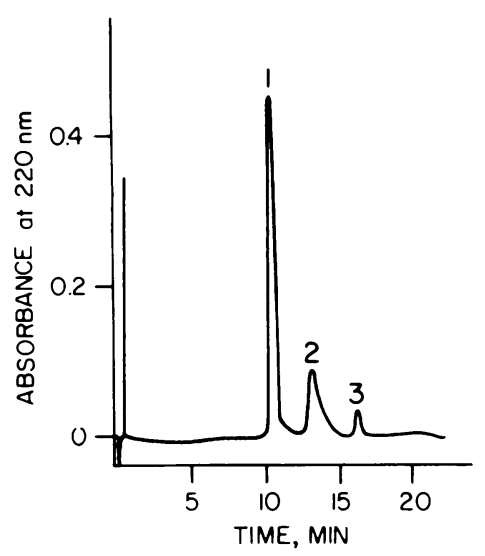

FIgURE 7 Reverse-phase HPLC of partially purified pancreatic immunoreactive somatostatin (fraction CMII) on a MCH 10 Micropack column $(0.4 \times 25 \mathrm{~cm})$. The column was eluted with a gradient of acetonitrile as described in the Methods at 1,100 $\mathrm{lb} / \mathrm{in} .^{2}, 1 \mathrm{ml} / \mathrm{min}$, room temperature. A total of $27 \mu \mathrm{g}$ of protein was applied. SRIF $(20 \mu \mathrm{g})$ was applied in a separate run and eluted at $6.5 \mathrm{~min}$ (not shown).

pancreatic polypeptide (mol wt, 4,500) and glucagon (mol wt, 3,500; Fig. 8, lane 7).

Another estimate of the molecular weight of pancreatic somatostatin was obtained by gel filtration chromatography on a Bio-Gel P-6 column in $8 \mathrm{M}$ urea (Fig. 9). This column was calibrated with aminoethylated $\beta$-chain and $\alpha$-chain of bovine insulin, as well as SRIF.

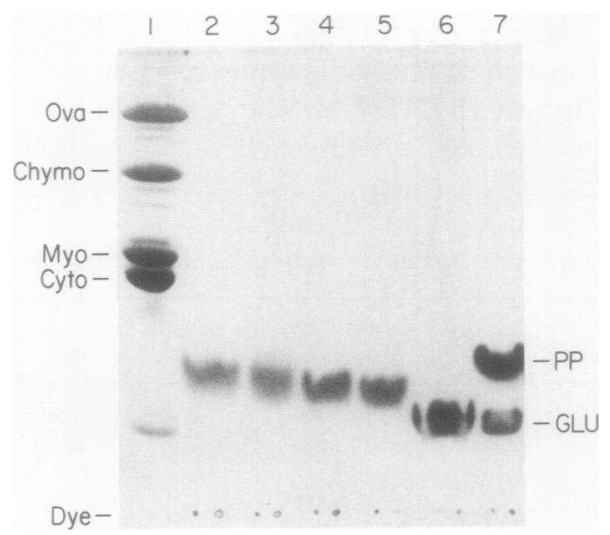

FIGURE 8 Electrophoresis of purified immunoreactive somatostatin on an SDS-urea polyacrylamide slab gel. Standard proteins, including lane 1 , ovalbumin (Ova), mol wt 43,000; chymotrypsinogen (Chy), mol wt 27,000; myoglobin (Myo), mol wt 17,000; cytochrome C (Cyto), mol wt 12,000; lane 6 , SRIF, mol wt 1,800; lane 7 , bovine pancreatic polypeptide (PP), mol wt 4,500; and bovine glucagon (GLU), mol wt 3,500. Samples (DEAE-cellulose fraction a from CM-cellulose fraction II, $\beta$ SH lane $2,+\beta$ SH lane 3 ; DEAE-cellulose fraction a from CM-cellulose fraction IV, $-\beta \mathrm{SH}$ lane $4,+\beta \mathrm{SH}$ lane 5) were electrophoresed on $17.5 \%$ polyacrylamide separating slab gel with a discontinuous buffer system and visualized by staining with Coomassie Blue as described in the Methods. 

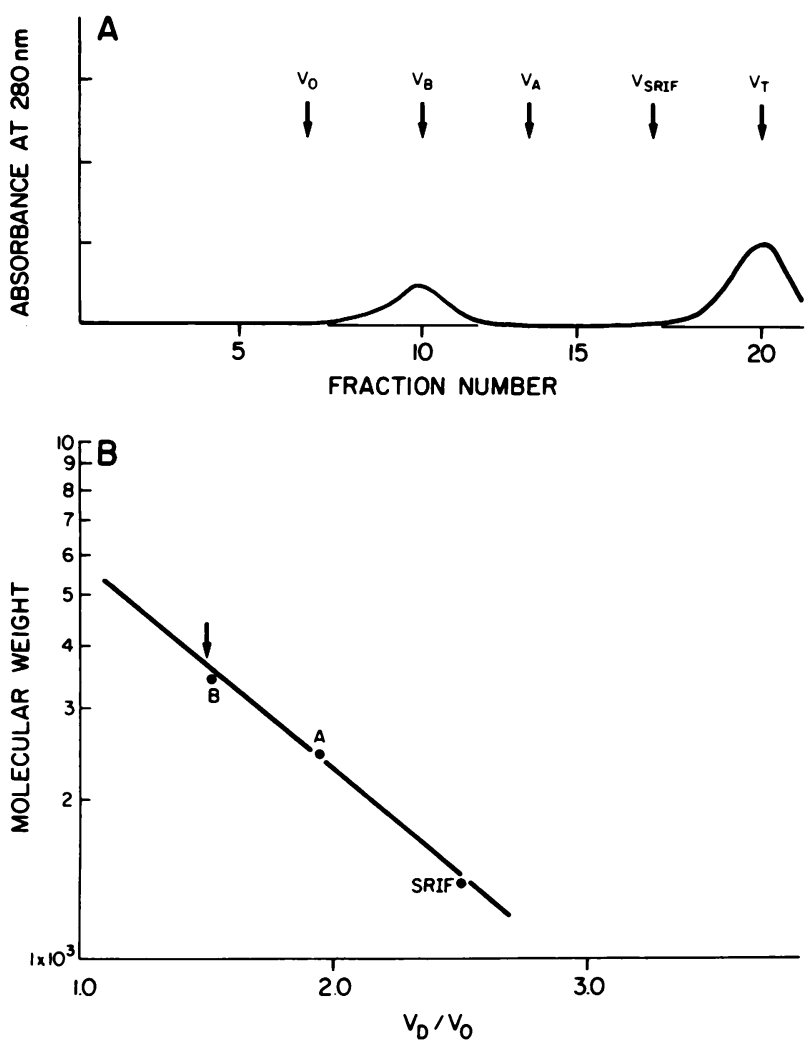

FIgURE 9 Molecular determination of immunoreactive pancreatic somatostatin. (A) DEAE fraction a from C.M-cellulose fraction II was reduced, carboxymethylated, and applied to a Bio-Gel P-6 column $(0.9 \times 27 \mathrm{~cm}, 0.01 \mathrm{M}$ Tris-8 $\mathrm{M}$ urea, $\mathrm{pH}$ 8.0) and chromatographed as described in the Methods. (Flow rate was $5.8 \mathrm{ml} / \mathrm{h}$ and the fraction size was $0.8 \mathrm{ml}$ ). The markers refer to the eluted position of blue dextran $\left(\mathrm{V}_{0}\right)$, aminoethylated bovine insulin $\beta$-chain $\left(V_{B}\right)$ and $\alpha$-chain $\left(V_{A}\right)$, carboxymethylated SRIF ( $\left.V_{\text {SRIF }}\right)$ and the included volume $\left(V_{T}\right)$. The absorbance peak at $V_{T}$ was due to the reagents added for reduction and carboxymethylation. (B) The ratios of distribution volume to void volume $\left(V_{D} / V_{0}\right)$ of the three standard peptides are plotted against the log of their molecular weight. The arrow shows the elution position of carboxymethylated DEAE fraction a from CM-cellulose fraction II. B: bovine insulin $\beta$-chain; A: bovine insulin $\alpha$-chain.

Pancreatic somatostatin (IIa) was seen to migrate slightly larger than aminoethylated $\beta$-chain of bovine insulin. The molecular weight estimation of 3,700 (Fig. 10B) is in close agreement with that observed by SDS-polyacrylamide gel electrophoresis.

Immunochemical studies. The immunochemical relationship of purified pancreatic somatostatins was compared with SRIF (Fig. 10). Serial dilution of a total pancreatic extract and of purified pancreatic somatostatin gave displacement curves parallel to that of SRIF in the radioimmunoassay (Fig. 10A). This indicated that the immunochemical determinants of the purified proteins that were recognized by this particular antibody were indistinguishable from those present in the crude extract. When the two pancreatic somatostatins were compared to SRIF on a weight basis (Fig. 10B) the displacement was identical and $\sim 25 \%$ that of synthetic somatostatin.

Amino acid composition and end-group analysis. The purified pancreatic somatostatins IIa and IVa were hydrolysed and subjected to amino acid analysis (Table II). In comparison of IVa to SRIF, there are two more basic residues, but five acidic residues, consistent with the electrophoretic mobility of pancreatic somatostatin relative to SRIF (Figs. 5 and 6). The composition of IIa and IVa were similar, and differed at most by 4 or 5 amino acids from each other. The estimate of 17 amino acids in IVa in excess of that in tetradecapeptide somatostatin is consistent with the molecular weight estimates. End-group analysis of IVa revealed only aspartic acid as $\mathrm{NH}_{2}$-terminal amino acid.

Bioassay. The purified, pancreatic somatostatins were tested for their ability to inhibit growth hormone release from isolated rat anterior pituitary cells. During a 3-h incubation (26), SRIF (1 $\mu \mathrm{M})$ inhibited growth hormone release $60.0 \pm 5.0 \%$ (mean $\pm \mathrm{SE}$ ), fraction IIa $(1 \mu \mathrm{M})$ inhibited $60.0 \pm 18.1 \%$, and fraction IVa $(1 \mu \mathrm{M})$ $65.0 \pm 8.7 \% .^{2}$

\section{DISCUSSION}

Fish islets are an excellent source for isolation of pancreatic somatostatin. Pancreatic islets make up $\sim 1 \%$ of the total pancreatic tissue in mammals and birds. In teleost fish, however, the endocrine pancreas is separate from the exocrine pancreas, and islets exist as fairly large endocrine organs weighing up to $60 \mathrm{mg}$ in 5 -lb fish (unpublished observation). Brinn reported a large quantity of somatostatin containing $\mathrm{D}$ cells in channel catfish (15). This has been confirmed by an immunocytochemical study in which insulin:somatostatin: glucagon-containing cells were present in a ratio of 9:6:4 in both anglerfish and catfish (5). $5 \mathrm{mg}$ of pancreatic somatostatin was isolated from islets obtained from $400 \mathrm{lb}$ of fish ( 100-150 fish). On the basis of previously published estimates (11-13), an equivalent somatostatin content would be present in 35,000 rat pancreases, or over 1,000 bird pancreases. The relationship between fish and mammalian pancreatic somatostatins has yet to be determined. The parallel immunoassay data suggest that the immunochemical determinants are very similar, but clearly not identical because fish pancreatic somatostatin displaces labeled synthetic somatostatin one-fourth as well as synthetic somatostatin from its antibody (on a molar basis this corrects to approximately one-half). Amino acid analysis does not contribute to the comparison because it is different from synthetic somatostatin, as is expected since the

\footnotetext{
${ }^{2}$. Manuscript in preparation.
} 

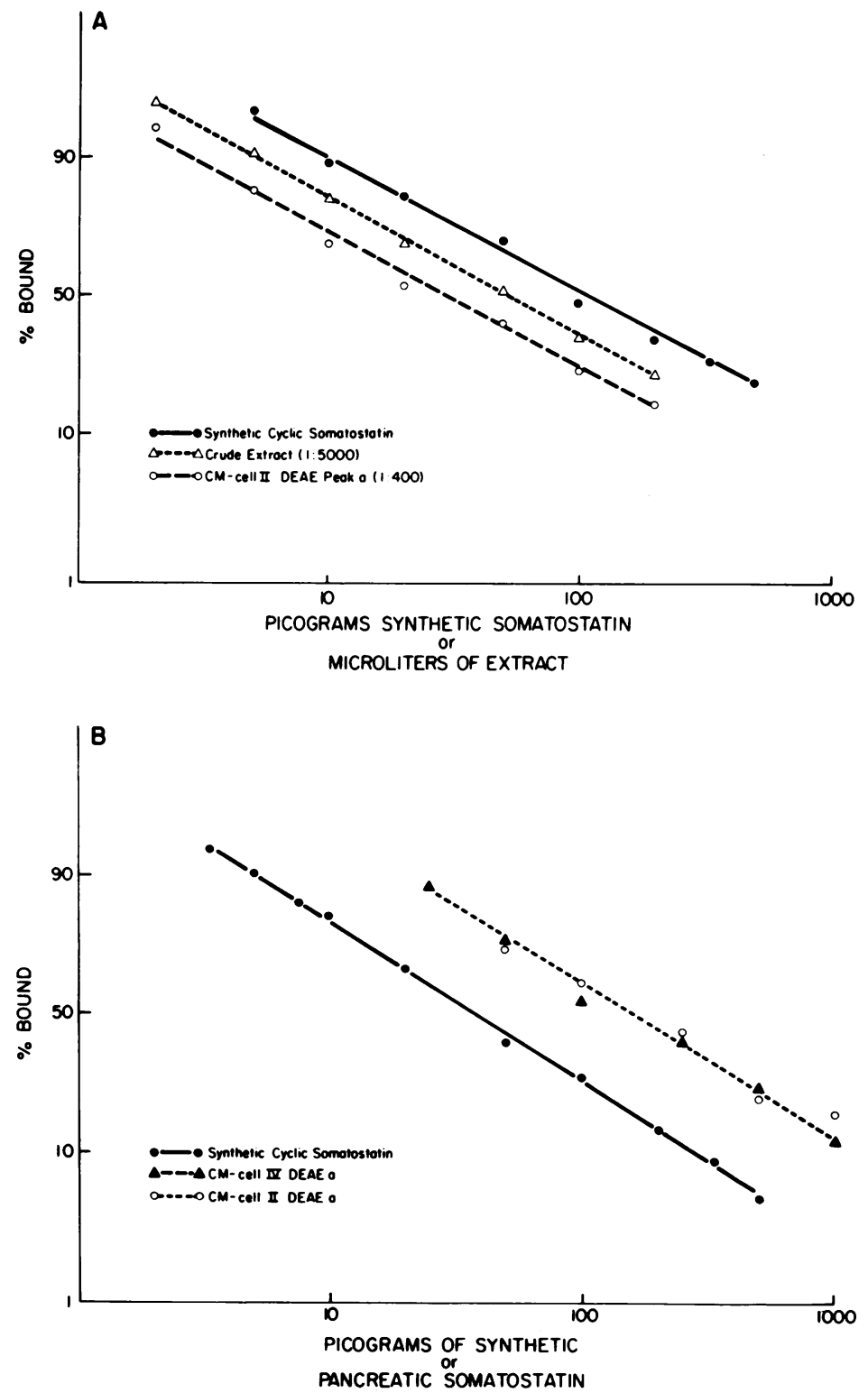

FIGURE 10 Radioimmunoassay of pancreatic somatostatin. (A) Displacement of ${ }^{125}$ I-SRIF from somatostatin antibody by purified pancreatic somatostatin (CM-cellulose fraction II DEAEcellulose peak a $[O]$ ), and crude extract $(\Delta)$, compared with that of synthetic somatostatin $(\bullet)$. (B) Dose-dependent displacement of ${ }^{125}$ I-somatostatin by purified pancreatic somatostatin products: SRIF (O); CM-cellulose IV DEAE-cellulose a (A); CM-cellulose II DEAE a (O).

fish somatostatins are bigger. Furthermore, the sequence of fish insulins differs from mammalian insulin in up to $50 \%$ of the amino acids, yet they maintain considerable biological activity in mammalian systems (28). The exact relationship of the fish pancreatic immunoreactive somatostatins to tetradecapeptide somatostatin awaits sequencing. This should prove interesting since Vale et al. (16) have demonstrated that somatostatin biological activity can be maintained with considerable changes in synthetic analogues.
Purification of pancreatic somatostatin from fish islet extracts was accomplished by propionic acid extraction followed by three chromatographic steps. It was anticipated that purification from fish islets would be simpler than from mammalian pancreas, since fish islets are 100 -fold enriched relative to mammalian islets embedded in exocrine pancreas. In fact, immunoreactive somatostatin comprised $0.8 \%$ of the total acid-soluble fish islet protein (Table I), which can be corrected to $3.2 \%$ on a weight basis because the 
TABLE II

Amino Acid Composition of Pancreatic Somatostatins

\begin{tabular}{|c|c|c|c|c|}
\hline \multirow[b]{2}{*}{ Amino acid } & \multicolumn{2}{|c|}{ Found } & \multirow[b]{2}{*}{ SRIF } & \multirow{2}{*}{$\begin{array}{l}\text { Excess in IVa } \\
\text { over SRIF }\end{array}$} \\
\hline & Ila & IVa & & \\
\hline Aspartic acid & 6.6 & 5.6 & 1 & +5 \\
\hline Threonine & 4.9 & 4.4 & 2 & +2 \\
\hline Serine & 4.3 & 3.3 & 1 & +2 \\
\hline Glutamic acid & 1.4 & 0.4 & - & +0 \\
\hline Proline & 2.2 & 1.8 & - & +2 \\
\hline Glycine & 1.9 & 0.6 & 1 & 0 \\
\hline Alanine & 2.5 & 1.8 & 1 & +1 \\
\hline Cysteine & $*$ & $1.8^{*}$ & 2 & 0 \\
\hline Valine & 1.0 & 1.0 & - & +1 \\
\hline Methionine & 0.4 & - & - & 0 \\
\hline Isoleucine & 0.4 & - & - & 0 \\
\hline Leucine & 2.3 & 2.2 & - & +2 \\
\hline Tyrosine & 1.5 & 0.5 & - & +1 \\
\hline Phenylalanine & 1.9 & 1.5 & 3 & -1 \\
\hline Histidine & 0.2 & 0.2 & - & 0 \\
\hline Lysine & 2.9 & 3.1 & 2 & +1 \\
\hline Arginine & 1.9 & 1.4 & - & +1 \\
\hline \multirow[t]{2}{*}{ Tryptophan } & 0.9 & 1.1 & 1 & 0 \\
\hline & & & 14 & +17 \\
\hline
\end{tabular}

All results are expressed assuming $1 \mathrm{~mol}$ valine/mol peptide. Hydrolysis was in $6 \mathrm{~N} \mathrm{HCl}$ as described in the Methods. Tryptophan was determined spectrophotometrically (27).

* Since hydrolysis was done on peptides not carboxymethylated, the cysteine determinations were approximate. The value for IVa has been confirmed by analysis of carboxymethylated material.

immunoassay has one-fourth the affinity for pancreatic somatostatin compared to SRIF. Criteria for purity of fish pancreatic somatostatins include: $(a)$ thin-layer electrophoresis of the purified material yielded one major peptide; when the major spot was eluted from thin-layer plates, the specific activity of the eluted peptides was not significantly different from that of the total preparation before electrophoresis; $(b)$ electrophoresis of fraction IIa on polyacrylamide gels revealed one band; (c) HPLC of fraction CM-cellulose II yielded one major protein peak, which contained all the immunoreactive somatostatin and had identical mobility of purified fraction CM-cellulose IIa on thin-layer electrophoresis; and $(d)$ end-group analysis of purified somatostatin (IVa) revealed only aspartic acid.

The first report of an estimate of the size of immunoreactive pancreatic somatostatin was reported in 1975 (11). Acid extracts of rat pancreas were chromatographed on a Sephadex G-25 column and the majority of the immunoreactive somatostatin eluted in the void volume. A small amount of somatostatin comigrated with the tetradecapeptide. It was noted that both big and small somatostatin from crude pancreas and stomach extracts displaced tracer in a manner parallel to that of synthetic somatostatin, indicating that the gastric and pancreatic somatostatin-like substances were immunologically indistinguishable from the somatostatin tetradecapeptide. Spiess et al. (13) found most of the somatostatin-like activity of pigeon pancreas was $1,500-2,500 \mathrm{~mol} \mathrm{wt}$, but a small amount of material 11,000-12,500 mol wt was also found. Noe et al. (29) incubated slices of anglerfish islets for several hours, then chromatographed acid extracts on Bio-Gel P-10. A small amount of high molecular weight immunoreactive somatostatin was observed, but the majority comigrated with the synthetic tetradecapeptide. Species differences, extraction methods, and varying affinity of antibodies for larger forms of somatostatin (30), may account for the differences observed. The chemical structure of the catfish pancreatic somatostatin has yet to be determined. Recently, a peptide with somatostatin-like immunoreactivity was isolated from acid extracts of porcine intestine (31). Preliminary chemical characterization suggested that it was somatostatin with an amino terminal extension of seven amino acids.

In the present study, the overwhelming majority of immunoreactive pancreatic somatostatin migrated in the region of insulin and glucagon by gel filtration chromatography, whereas only a small amount of immunoreactive somatostatin was detected in larger and smaller fractions. Further purification of this fraction yielded two peptides of identical size, $\sim 3,700 \mathrm{~mol} \mathrm{wt}$. Rechromatography on Bio-Gel in the presence of $8 \mathrm{M}$ urea, as well as electrophoresis under denaturing conditions after being boiled in SDS, ruled out the possibility of nonspecific aggregation or binding to other islet proteins. Since these peptides were extracted from fresh frozen islets under conditions where proteolysis was minimized, they probably represent the major storage form of immunoreactive somatostatin present in pancreatic islets. Amino acid analysis suggested that the two peptides are very similar, and differ at most by four or five amino acids. The differences observed between the fish pancreatic somatostatins and hypothalamic tetradecapeptide somatostatin could be due to either species or tissue differences. Both peptides have full biological activity relative to SRIF inhibition of growth hormone release at $1 \mu \mathrm{M}$. We have not evaluated other concentrations to evaluate relative potencies. Other biological activities and receptor binding studies may be informative.

\section{ACKNOWLEDGMENTS}

The authors wish to thank Dr. Ralph Bradshaw for assistance with amino acid analysis and Dr. Jeanne Martin for the bioassay, and both for helpful discussions and review of the manuscript. HPLC was performed with the assistance of Dr. Jim Davis and David Calvin. The manuscript was prepared by Ms. Jane Pace.

This work was supported by National Institutes of Health 
grants AM-25940 and AM-15019, and a grant from the St. Louis Diabetic Children's Welfare Association.

\section{REFERENCES}

1. Brazeau, P., W. Vale, R. Burgus, N. Ling, M. Butcher, J. Rivier, and R. Guillemin. 1973. Hypothalamic polypeptide that inhibits the secretion of immunoreactive pituitary growth hormone. Science (Wash. D. C.). 179: 77.

2. Vale, W., C. Rivier, and M. Brown. 1977. Regulatory peptides of the hypothalamus. Ann. Rev. Physiol. 39: 473.

3. Dubois, M. P. 1975. Immunoreactive somatostatin is present in discrete cells of the endocrine pancreas. Proc. Natl. Acad. Sci. U. S. A. 72: 1340.

4. Goldsmith, P. C., J. C. Rose, A. Arimura, and W. F. Ganong. Ultrastructural localization of somatostatin in pancreatic islets of the rat. Endocrinology. 97: 1061.

5. Johnson, D. E., J. L. Torrence, R. P. Elde, G. E. Bauer, B. D. Noe, and D. J. Fletcher. 1976. Immunohistochemical localization of somatostatin, insulin and glucagon in the principal islets of the anglerfish (Lophius Americanus) and the channel catfish (Ictalurus Punctata). Am. J. Anat. 147: 119.

6. Koerker, D. J., W. Ruch, E. Chideckel, J. Palmer, C. J. Goodner, J. Ensinck, and C. C. Gale. 1974. Somatostatin: Hypothalamic inhibitor of the endocrine pancreas. Science (Wash. D. C.). 184: 482.

7. Schusdziarra, V., E. Ipp, V. Harris, R. E. Dobbs, P. Raskin L. Orci, and R. H. Unger. 1978. Studies of the physiology and pathophysiology of the pancreatic D-cell. Metab. Clin. Exp. 27(Suppl. 1): 1227.

8. Schusdziarra, V., V. Harris, J. M. Conlon, A. Arimura, and R. H. Unger. 1978. Pancreatic and gastric intraduodenal nutrients and $\mathrm{HCl}$ in the dog. J. Clin. Invest. 62: 509.

9. Schusdziara, V., V. Harris, A. Arimura, and R. H. Unger. 1979. Evidence for a role of splanchnic somatostatin in the homeostasis of ingested nutrients. Endocrinology. 104: 1705 .

10. Schully, R. E., J. J. Galdabini, and B. U. McNeely, editors. 1978. Case Records of the Massachusetts General Hospital: Weekly Clinicopathological Exercises. 299: 241.

11. Arimura, A., H. Sato, A. Dupont, N. Nishi, and A. V. Schally. 1975. Somatostatin: Abundance of immunoreactive hormone in rat stomach and pancreas. Science (Wash. D. C.). 184: 482.

12. Weir, G. C., P. C. Goltsos, E. P. Steinberg, and Y. C. Patel. 1976. High concentration of somatostatin immunoreactivity in chicken pancreas. Diabetologia. 12: 129.

13. Spiess, J., J. E. Rivier, J. A. Rodkey, C. D. Bennett, and W. Vale. 1979. Isolation and characterization of somatostatin from pigeon pancreas. Proc. Natl. Acad. Sci. U. S. A. 76: 2974.

14. Larsson, L.-I., J. J. Holst, C. Kuhl, G. Lundqvist, M. A. Hirsch, S. Ingemansson, S. Lindkaer Jensen, J. F. Rehfeld, and T. W. Schwartz. 1977. Pancreatic somatostatinoma:
Clinical features of physiological implications. Lancet. I: 666 .

15. Brinn, J. E. 1971. The pancreatic islet cells of the channel catfish, Ictalurus punctatas. Anat. Rec. 169: 284

16. Vale, W., N. Ling, J. Rivier, J. Villarreal, C. Rivier, C. Douglas, and M. Brown. 1976. Anatomic and phylogenetic distribution of somatostatin. Metab. Clin. Exp. 25(Suppl. 1): 1491 .

17. Albert, S. G., and M. A. Permutt. 1979. Proinsulin precursors in catfish pancreatic islets. J. Biol. Chem. 254: 3483.

18. Hirs, C. H. W. 1976. Methods Enzymol. XI: 199.

19. Raftery, M. A., and Cole, R. D. 1966. On the aminoethylation of proteins. J. Biol. Chem. 241: 3457.

20. Swank, R. T., and K. D. Munkres. 1971. Molecular weight analysis of oligopeptides by electrophoresis in polyacrylamide gel with sodium dodecyl sulfate. Anal. Biochem. 39: 462 .

21. Laemmli, U. K. 1970. Cleavage of structural proteins during the assembly of the head of bacteriophage $T_{4}$. Nature (Lond.). 227: 680.

22. Hirsch, H. J., and K. H. Gabbay. 1978. Radioimmunoassay of somatostatin-like immunoreactivity (SLI) in human plasma. Diabetes. 27: 441.

23. Lowry, O. H., Rosebrough, N. J., Farr, A. L., and R. J. Randall. 1951. Protein measurement with the folin phenol reagent. J. Biol. Chem. 193: 265.

24. Davis, B. J. 1964. Disc electrophoresis-II: Method and application to human serum proteins. Ann. N. Y. Acad. Sci. 121: 404.

25. Edman, P., and G. Begg. 1967. A protein sequenator. Eur. J. Biochem. 1: 80.

26. Martin, J. E., and C. Sattler. 1979. Developmental loss of acute inhibitory effect of melatonin on the in vitro pituitary luteinizing hormone and follicle-stimulating hormone responses to luteinizing hormone-releasing hormone. Endocrinology. 105: 1007.

27. Edelhoch, H. 1967. Spectroscopic determination of tryptophan and tyrosine in proteins. Biochemistry. 6: 1948.

28. Peterson, J. D., Steiner, D. F., Emdin, S. O., and Falmker, S. 1975. The amino acid sequence of the insulin from a primitive vertebrate, the Atlantic Hagfish (Myxine glutinosa). J. Biol. Chem. 250: 5183.

29. Noe, B. D., D. J. Fletcher, G. E. Bauer, G. C. Weir, and Y. Patel. 1978. Somatostatin biosynthesis occurs in pancreatic islets. Endocrinology. 102: 1675.

30. Spiess, J., and W. Vale. 1978. Investigation of larger forms of somatostatin in pigeon pancreas and rat brain. Metab. Clin. Exp. 27(Suppl. 1).: 1175.

31. Pradayrol, L., J. A. Chayvialle, M. Carlquist, and V. Mutt. 1978. Isolation of a porcine intestinal peptide with $C$ terminal somatostatin. Biochem. Biophys. Res. Commun. 85: 701 . 